\title{
Teknologi Komunikasi Informasi Untuk Peningkatan Kesadaran Publik Pada Organisasi Sosial
}

\author{
Diah Ayu Candraningrum \\ Fakultas Ilmu Komunikasi Universitas Tarumanagara \\ J1. Letjen S Parman No 1, Jakarta Barat 11440 \\ diahc@fikom.untar.ac.id
}

\begin{abstract}
In today's digital era, the need for social media use to achieve goals must be understood, no exception for social organizations. One of them is the Breastfeeding Mothers Association (AIMI), West Sumatra Province. The AIMI branch of the City of Padang also has to socialize the campaign program and policies of its parent organization. But the problem faced is that not all members understand the use of social media to disseminate information and gain public sympathy. Therefore, the problem raised in this research is how the use of AIMI's West Sumatra social media as part of its personal branding strategy, to increase public brand awareness. The theory used is the Personal Branding Theory. The research itself was conducted through a descriptive qualitative research approach with interview techniques, combined with data collection by distributing $e$ questionnaires to 20 AIMI Padang members and 5 external parties. The result, it is known that the level of understanding of AIMI members in the use of social media to increase public awareness is still lacking, so that an understanding of the use of comprehensive information communication technology is needed.
\end{abstract}

Keyword: brand awareness, personal branding, social media

\begin{abstract}
Abstrak
Di era digital saat ini, kebutuhan akan penggunaan media sosial untuk mencapai tujuan harus dipahami caranya, tak terkecuali bagi organisasi sosial. Salah satunya Asosiasi Ibu Menyusui (AIMI) Provinsi Sumatra Barat. AIMI cabang Kota Padang juga harus mensosialisasikan program kampanye dan kebijakan induk organisasinya. Namun permasalahan yang dihadapi adalah bahwa tak semua anggotanya memahami penggunaan media sosial untuk menyebarkan informasi dan meraih simpati publik. Karena itu, permasalahan yang diangkat dalam penelitian ini adalah bagaimana penggunaan media sosial milik AIMI Sumatra Barat sebagai bagian dari strategi personal branding-nya, untuk meningkatkan brand awareness masyarakat. Teori yang digunakan adalah Teori Personal Branding. Penelitian ini sendiri dilakukan lewat pendekatan penelitian kualitatif yang bersifat deskriptif dengan teknik wawancara, dikombinasikan dengan pengumpulan data dengan pembagian e-kuesioner kepada 20 orang anggota AIMI Padang dan 5 orang dari pihak eksternal. Hasilnya, diketahui bahwa tingkat pemahaman anggota AIMI dalam penggunaan media sosial untuk peningkatan kesadaran publik masih kurang, sehingga diperlukan pemahaman tentang penggunaan teknologi komunikasi informasi yang komprehensif.
\end{abstract}

Kata Kunci: brand awareness, media sosial, personal branding 


\section{Pendahuluan}

Kegiatan menyusui bukanlah kegiatan yang mudah bagi kalangan ibu yang baru saja menjalani proses kelahiran bayinya. Sejumlah wanita pada kelompok ibu dan bayi di Northampton mengatakan kepada Newsbeat bahwa menyusui itu sulit dan menyakitkan. Mereka mengeluhkan banyaknya keluhan fisik yang dialami saat seorang ibu menyusui bayinya (BBC, 2015).

Karena itu, pentingnya pemberian informasi dan pemahaman kepada kalangan ibu yang baru melahirkan, supaya mereka tak depresi dan disalahkan pihak keluarga karena dianggap ibu yang tak bertanggung jawab (Windratie, 2015). Di tengah-tengah realitas sosial tersebut, muncullah Asosiasi Ibu Menyusui Indonesia (AIMI) sebagai asosiasi yang diinisiasi sekelompok ibu yang memiliki kepedulian mengenai pentingnya menyusui dan memberikan ASI eksklusif.

Berdiri secara resmi pada 21 April 2007, inisiasi ini kemudian berkembang pesat hingga ke beberapa kota di Indonesia. Daya jangkaunya juga lewat optimalisasi website resmi, juga pemanfaatan jejaring sosial seperti mailing list, Twitter, Facebook, dan juga fasilitas RSS untuk menyebarkan artikel yang berhubungan dengan kesehatan dalam kegiatan menyusui (AIMI, n.d.). Di tahun 2015 saja jumlah pengikut di akun Twitter @aimi_asi telah mencapai lebih dari 73.000, dan anggota group Facebook yang di tahun 2012 baru berjumlah 13.000 anggota. Angka ini melonjak pesat di pertengahan bulan Oktober 2014 yang telah mendekati angka 120.000 (Nunik Maharani Hartoyo, 2015).

Salah satu cabangnya yakni AIMI cabang Sumatra Barat, pemilik akun Instagram@aimisumbar ini memiliki jumlah pengikut di Instagram sekitar 1270 akun. Semakin banyak jumlah pengikut, timbul masalah bagaimana cara mengelola media sosial supaya efektif untuk meningkatkan personal branding organisasinya. Untuk itu, penelitian ini akan membahasnya lewat teori media sosial dan teori personal banding.

Dalam kasus AIMI ini, personal branding dibutuhkan guna membangun identitas baik organisasi maupun anggota organisasi di dalam AIMI guna mendukung advokasi publik mengenai kesadaran pentingnya menyusui. Merek atau brand sendiri merupakan nama atau simbol yang bersifat membedakan, dengan maksud mengidentifikasi barang atau jasa dari seorang penjual atau sekelompok penjual tertentu. Berbeda dengan produk keluaran yang bisa secara fisik disentuh, brand adalah sesuatu yang intangible, tetapi efeknya sangat nyata (Kotler, 2013).

Haroen (2012) mengemukakan bahwa, branding adalah aktivitas yang dilakukan untuk membangun persepsi dan kepercayaan orang lain dan merupakan kebutuhan dari semua orang yang memiliki kepentingan untuk mendapatkan sesuatu dari orang lain melalui proses komunikasi.

Pada dasarnya, personal branding adalah sebuah proses agar orang lain mengenal, mengelola dan mempersepsikan personal brand yang dimiliki, untuk mencapai tujuan yang telah direncanakan (Haroen, 2012). Pemasaran bagi organisasi nirlaba seperti AIMI berada dalam lingkup social marketing yang membutuhkan penanganan khusus karena membutuhkan keterlibatan masyarakat. Sedangkan pengelolaan media sosial yang dilakukan, seperti terdapat dalam Teori 
Diah Ayu Candraningrum :Teknologi Komunikasi Informasi Untuk Peningkatan Kesadaran Publik Pada Organisasi Sosial

Media Sosial, yang menjadi turunan dari Teori Media Baru. Menurut Meike dan Young dalam Nasrullah (2017), media sosial adalah konvergensi antara komunikasi personal dalam arti saling berbagi antara individu (to be shared oneto-one) dan media publik untuk berbagi kepada siapapun tanpa ada kekhususan individu.

Di media inilah, pengguna dapat mempresentasikan dirinya ataupun berinteraksi, bekerjasama, berbagi, berkomunikasi dnegan pengguna lain dan membentuk ikatan sosial secara virtual. Hal ini dapat terjadi karena media sosial memiliki karakter yang sangat menonjol. Karaksteristik yang dimiliki media sosial adalah: jaringan (network), informasi, arsip (archieve), interaksi (interactivity), simulasi sosial (simulation of society), konten oleh pengguna (user generated content) (Nasrullah, 2017).

Aspek jaringan (network) memiliki jaringan sosial, yang artinya mampu menjadi medium bagi pengguna untuk terhubung secara tekhnologi. Aspek informasi (information) berarti media sosial mampu membuat representasi identitasnya, menghasilkan konten dan berinteraksi layaknuya informasi. Demikian dengan aspek penyimpanan atau arsip (archieve), dimana semua informasi dapat diakses kapanpun dengan perangkat apapun. Juga aspek interaksi (interactivity), dimana saat penggunaan media sosial akan terjalin interaksi misalnya dengan pemberian komentar, pemberian simbol like atau berbagi informasi. Aspek simulasi sendiri menggambarkan interaksi dengan menggambarkan realitas dan interaksi yang terjadi, dimana representasi oleh media menjadi realitas sendiri yang terkadang berbeda atau bertolak belakang. Sedangkan aspek Konten oleh Pengguna (User and Degeneration) dapat diartikan bahwa segala persepsi di media sosial, semuanya sangat berdasarkan kontribusi pengguna akun. Hal ini menunjukkan, masyarakat tidak hanya mengkonsumsi content yang dibuat orang lain, namun menjadi produsen content di platform medianya sendiri. Aspek selanjutnya adalah penyebaran (share). Aspek ini merupakan bukti nyata bahwa sebuah konten yang diunggah, jika menarik, akan disebarkan secara aktif melalui akun yang lain. Indikatornya, banyak akun yang membagikan informasi yang dianggap penting dan menarik, juga adanya keberpihakan publik yang tengah berlibur dari pengunjung. (Nasrullah, 2017).

Menurut Chris Heuer dalam Solis (2010) dalam Kinanti dan Putri (2017), terdapat empat $\mathrm{C}$ dalam penggunaan media sosial, yakni: (1) Context: "How we frame our stories" yang diartikan sebagai cara mengirim informasi dengan memperhatikan bahasa ataupun isi dari pesan yang akan disampaikan; (2) Communication: "The practice of sharing story as well as listening, responding and growing" yang berarti berbagi informasi lewat bermacam cara (mendengar, merespon) yang nyaman bagi pengguna, sehingga pesan dapat tersampaikan dengan baik; (3) Collaboration: "Working together to make things better and more efficient and effective" yang tak lain adalah bagaimana kerjasama antara dua pihak (akun atau perusahaan dengan pengguna di media sosial) mampu membuat segala hal menjadi lebih efektif dan efisien; (4) Connection: "The relationships we forge and maintain" yakni bagaimana memelihara hubungan yang telah terbina sehingga pengguna merasa lebih dekat dengan perusahaan pengguna media sosial. 
Dengan penjelasan di atas, permasalahan yang diangkat dalam penelitian ini adalah: bagaimana cara membangun dan meningkatkan pengetahuan dan tingkat kesadaran publik, akan pentingnya kegiatan menyusui lewat penggunaan teknologi komunikasi informasi. Karena kegiatan ini perlu dilakukan dalam rangka membangun dukungan publik terhadap AIMI.

\section{Metode Penelitian}

Jenis penelitian ini adalah penelitian dengan pendekatan kualitatif yang bersifat deskriptif. Penelitian deskriptif sendiri bertujuan untuk memberikan gambaran tentang keadaan dan gejala sosial tertentu (Kriyantono, 2007). Untuk mendapatkan informasi yang lebih komprehensif, teknik pengumpulan data dilakukan lewat proses wawancara dan juga melakukan e-survei sehingga diharapkan bisa mendapatkan gambaran keadaan yang lebih menyeluruh. Tujuan dari penelitian ini adalah mencari cara mengelola media sosial untuk menyebarluaskan program-program AIMI Padang.

Obyek dalam penelitian ini adalah kelompok internal dan eksternal AIMI Padang. Kelompok internal terdiri atas perempuan anggota AIMI Padang yang aktif dalam berbagai kegiatan organisasinya. Total jumlah anggota AIMI Padang yang aktif saat ini sebanyak 20 orang. Mereka semua dipilih menjadi responden, karena hingga saat ini, AIMI Padang belum memiliki petugas administrasi khusus untuk menjalankan kegiatan media sosial sehingga semua. Sedangkan untuk kelompok eksternal, terdapat 5 orang pekerja LSM lain yang turut mengisi kuesioner. Mereka dinilai memiliki tingkat engagement yang kuat dengan media sosial milik AIMI Padang, baik sebagai pengikut atau followers.

Metode pengumpulan data dalam penelitian ini terbagi atas beberapa cara, antara lain: 1) Wawancara, metode ini digunakan secara langsung terkait penggunaan media sosial milik AIMI Padang. Wawancara dilakukan terhadap Ketua AIMI Padang Ria Oktorina dan juga beberapa warga lokal yang bukan anggota AIMI, namun mereka mengikuti perkembangan media sosial AIMI. 2) Kuesioner elektronik, metode ini digunakan untuk mendapatkan informasi secara tidak langsung, baik dari pengurus dan anggota AIMI, serta non anggota AIMI. dengan mengisi kuesioner yang telah disediakan. Kuesioner diberikan kepada anggota dan pengurus AIMI Padang, juga lembaga sosial lain di luar AIMI Padang.

\section{Hasil Penemuan dan Diskusi}

Kegiatan pembagian kuesioner dilakukan secara elektronik menggunakan Google Form. Kegiatan ini dilakukan sebelum para peserta mengikuti kegiatan workshop yang diselenggarakan oleh AIMI Padang. Kuesioner ini sendiri diikuti oleh seluruh anggota aktif IMI Padang yang mengikuti workshop dan beberapa anggota organisasi nirlaba lain yang hadir di kegiatan tersebut. Jumlah total peserta adalah 25 peserta, dengan perincian: 20 anggota dan pengurus AIMI Padang, 3 anggota dan pengurus NGO lokal lain di Padang dan 2 lainnya adalah dua jurnalis peliput kegiatan, yang banyak bersinggungan dengan berbagai 
Diah Ayu Candraningrum :Teknologi Komunikasi Informasi Untuk Peningkatan Kesadaran Publik Pada Organisasi Sosial

kegiatan AIMI Padang. Kelimanya juga termasuk follower akun Instagram AIMI Padang. Kuesioner ini bertujuan untuk mengetahui sejauh mana tingkat pengetahuan responden terhadap penggunaan media sosial untuk promosi organisasi.

Hasilnya secara umum, diketahui bahwa masing-masing peserta memiliki ketertarikan yang berbeda terhadap isi media sosial yang dimiliki AIMI Sumatra Barat. Paling tinggi adalah informasi dalam bentuk infografis, disusul kemudian oleh adanya informasi.

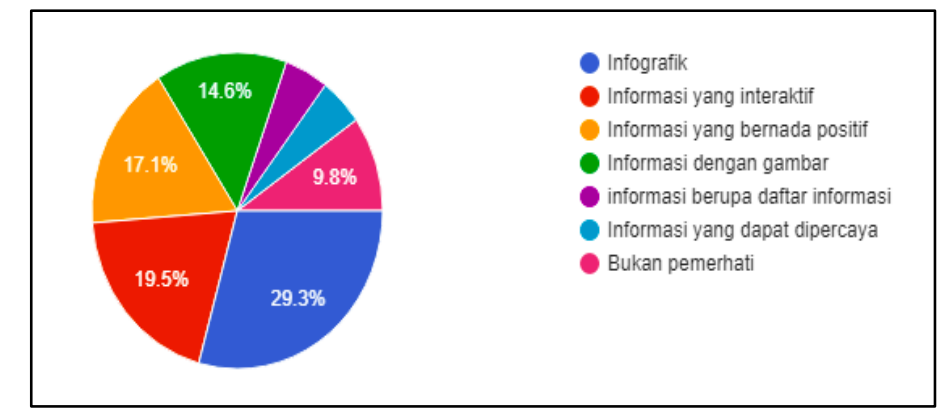

Gambar 1: Isi Media Sosial AIMI Sumatra Barat

Menurut Ketua AIMI Padang Ria Oktorina, pemilihan content media sosial di akun Instagram resmi AIMI Padang memang dikelola bersama, termasuk juga pemilihan isinya. Mayoritas jenis content yang sering diunggah adalah tentang infografis.

"Karena infografis dianggap lebih menarik daripada sekedar teks. Dan kebetulan, ada anggota kami yang khusus mengerjakan." (Ketua AIMI Padang Ria Oktorina dalam wawancara April 2018).

Namun meski bisa menilai isi (content) media sosial AIMI Sumatra Barat, tidak semua anggota mengerti dan memahami cara mengelola media sosial organisasinya. Hal ini terlihat dari jawaban kuesioner yang menjawab ya $(65,1 \%)$ serta menjawab tidak (34,9\%). Dijelaskan oleh Ketua AIMI Padang Ria Oktorina bahwa setiap anggota AIMI berhak mengunggah hal-hal yang terkait dengan organisasi di media sosial resmi AIMI.

"Selama ini, memang belum semua anggota AIMI Padang yang rajin mengunggah isi media sosial. Beberapa sudah melakukannya, namun kami tak membuat rencana publikasi. Jadi berjalan apa adanya. Isinya lebih ke informasi program organisasi atau kegiatan acara yang dilakukan oleh AIMI." (Ria Oktorina) 


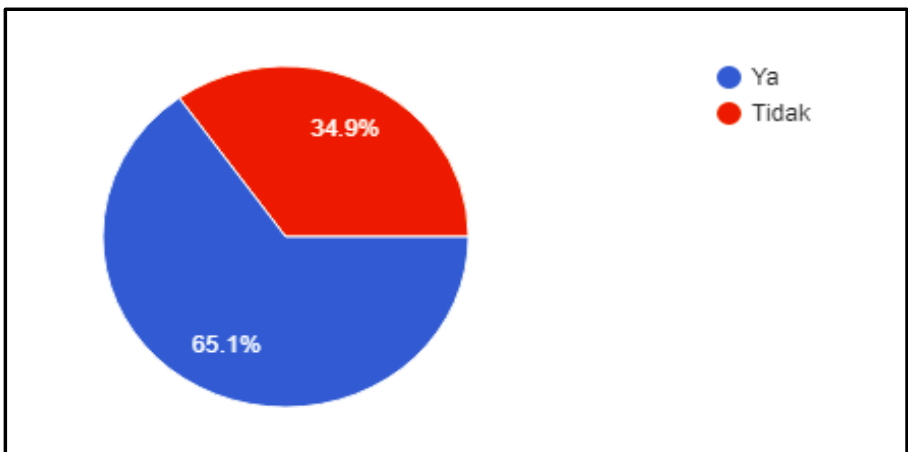

Gambar 2: Kemampuan Mengelola Media Sosial Organisasi

Para responden pun banyak yang mengetahui dan memahami cara mengelola media sosial organisasi untuk kegiatan social marketing. Terlihat dari jawaban kuesioner yang terdiri atas jawaban ya $(53,5 \%)$ dan jawaban tidak (46,5\%). Menurut Ria, pihaknya tidak mengenal definisi konsep social marketing. Namun pihaknya mengetahui kebutuhan apa yang diharapkan oleh sebuah organisasi sosial dalam menyiapkan etalase digitalnya supaya menarik untuk dikonsumsi publik.

"Kami hanya memposting isi media sosial dengan hal-hal yang terkait dengan organisasi saja. Kalau dianggap menarik dan mampu menambah jumlah anggota baru atau mendatangkan funding, ya kami anggap itu bonus." (Ria Oktorina)

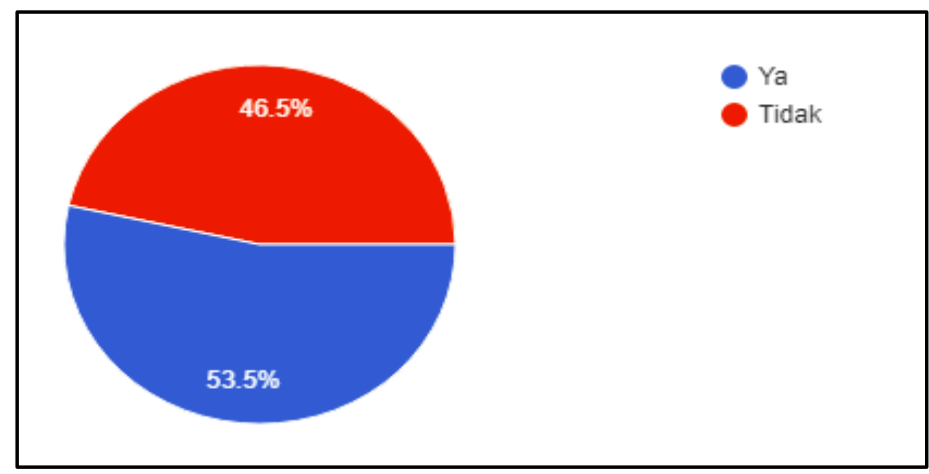

Gambar 3: Kemampuan Mengelola Sosial Marketing Organisasi

Kemampuan mengelola media sosial terebut tidak sebanding dengan upaya branding yang dilakukan AIMI. Karena ternyata belum semua pihak mengetahui cara melakukan upaya branding organisasi supaya lebih dikenal di masyarakat dan menarik hati masyarakat. Padahal hal ini penting supaya programprogram yang dijalankan AIMI dapat diterima di masyarakat. Terbukti hanya sebanyak 53,5\% responden yang mengaku bisa melakukan upaya social marketing lewat media sosial sebagai bagian dari branding organisasi. Sedangkan $46,5 \%$ lain mengaku tidak bisa. 


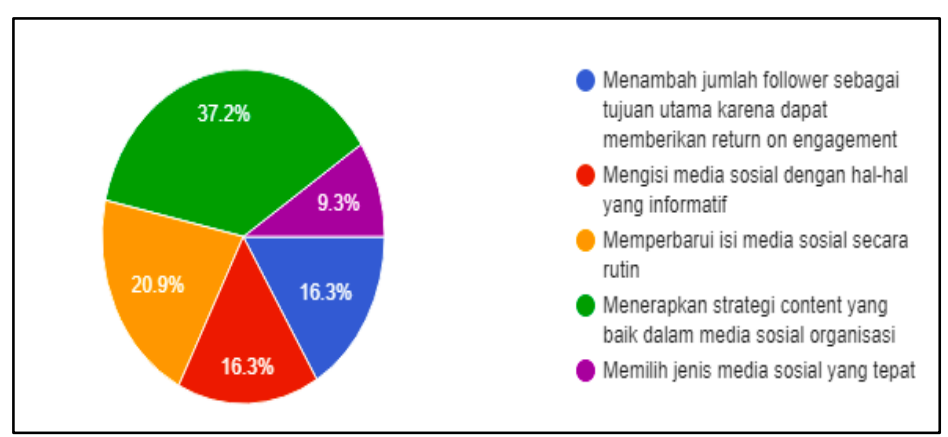

Gambar 4: Manfaat Pengelolaan Media Sosial Bagi Organisasi

Secara keseluruhan, seluruh responden telah memahami penggunaan media sosial untuk kepentingan organisasi dimana salah satu cara yang dapat dilakukan adalah dengan pendekatan social marketing. Dari hasil kuesioner yang dibagikan, poin tertinggi diraih untuk pemahaman content strategy yang baik dalam media sosial organisasi $(37,2 \%)$ karena dianggap memiliki banyak manfaat bagi individu maupun organisasi.

Dari gambaran di atas, terlihat jelas bahwa belum semua anggota AIMI Padang mengelola media sosial organisasi untuk kepentingan organisasi. Selama ini, mereka hanya sekedar melakukan posting yang menjelaskan kegiatan mereka. Tujuannya, untuk menyebarluaskan citra organisasi yang eksistensinya diakui banyak pihak. Namun sebenarnya, meski belum menjadi rutinitas, AIMI Padang telah menerapkan content strategi yang tepat melalui isi media sosial, yakni membuat infografik. Terbukti, content infografik menjadi salah satu content favorit para pengikut media sosial AIMI Sumatra Barat (29,3\%).

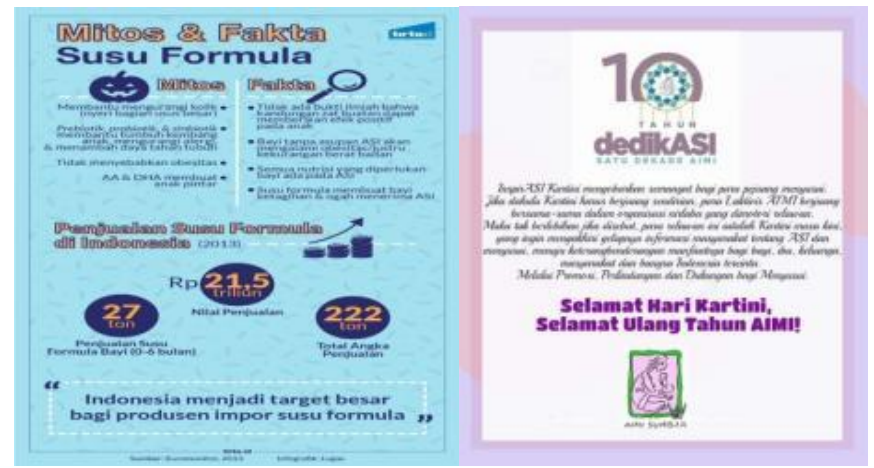

Gambar 5: Bentuk Content Strategy AIMI Sumatra Barat

Dari contoh tiga content yang diposting di akun Instagram resmi AIMI Padang di atas, terlihat bahwa content strategy yang dimiliki AIMI Padang sangat tepat. Tidak hanya menarik secara artisitik, melainkan juga informatif. Hal ini sesuai dengan konsep yang terdapat pada Teori Media Sosial, dimana sebuah posting di media sosial akan mampu menarik perhatian khalayak jika menjadi viral.

Dari gambaran ini juga menunjukkan, upaya branding organisasi yang dilakukan oleh pihak AIMI Sumatra Barat ini telah sesuai dengan perkembangan jaman yakni menggunakan media sosial sebagai sarana komunikasi. Sebab di era 
digital seperti sekarang, media sosial memag menjadi pilihan utama bagi masyarakat dalam mendapatkan informasi. Dan pengelola akun AIMI Sumatra Barat mengerti benar bahwa informasi yang mereka sampaikan melalui media sosial akan menjadi salah satu sarana penting untuk membangun eksistensi organisasi, khususnya dalam hal sebagai agen perubahan dan juga fungsi fundrising.

Teknik komunikasi yang diterapkan di media sosial AIMI Sumatra Barat adalah dengan pendekatan content media baru, dimana mereka lebih mengedepankan content infografik meski masih bersifat grafis 2 dimensi. Karena di era modern seperti saat ini, masyarakat lebih aware dengan tampilan teks disertai bentuk visual daripada teks murni. Hal ini membuat pesan yang ingin disampaikan organisasi bisa diterima banyak pihak. Bahkan tak jarang pula, banyak pihak lain yang mem-viral-kan pesan tersebut. Hal ini tentu saja menambah naiknya brand existence dari organisasi itu sendiri.

Keberadaan infografis yang menarik di media sosial yang juga berfungsi sebagai etalasse digital AIMI Padang ini juga memiliki manfaat lain yang tak kalah penting. Bukan hanya sekedar pemberian informasi kepada khalayak, melainkan juga sebagai ajang unjuk gigi mengenai prestasi dan profil diri. Diakui oleh Ketua AIMI Padang bahwa media sosial resmi organisasinya juga menjadi sumber informasi tidak hanya untuk mengetahui informasi tentang ibu dan anak. Media sosial yang dikelolanya ini juga menjadi sumber informasi bagi calon donator untuk melihat lebih dalam siapa saja orang-orang yang bekerja di dalam AIMI Sumatra Barat, apa saja prestasinya dan bagaimana sepak-terjang mereka selama ini.

\section{Simpulan}

Dari hasil penelitian ini, peneliti dapat menyimpulkan bahwa AIMI Sumatra Barat telah melakukan kegiatan branding organisasi yang tepat melalui media sosial. Kegiatan tersebut tentu saja berkontribusi besar terhadap organisasi. Karena dengan pemilihan content strategy yang tepat, media sosial yang dimiliki AIMI Padang ini telah menjadi juru bicara yang baik yang mampu meningkatkan image organisasi di mata publik.

Namun, pengelolaan content media sosialnya belum dilakukan secara profesional. Artinya, semua orang bisa memposting content apapun di sana. Sebaiknya perlu ditunjuk satu atau dua orang saja sebagai administrator, supaya content yang ditampilkan lebih beragam. Juga diperlukan time management yang tepat dalam pengaturan dan publikasi content, supaya pesan yang ingin disampaikan lebih mudah ditangkap oleh khalayak yang dituju.

Selain itu, AIMI Sumatra Barat belum memahami konsep sosial marketing dalam penyampaian hasil kegiatan atau prestasi organisasi. Padahal konsep ini tengah popular saat ini dan menjadi salah satu strategi komunikasi dan penyampaian pesan yang efektif, yang tentunya akan berkontribusi besar terhadap image dan kinerja organisasi. 
Diah Ayu Candraningrum :Teknologi Komunikasi Informasi Untuk Peningkatan Kesadaran Publik Pada Organisasi Sosial

\section{Ucapan Terima Kasih}

Dalam menyelesaikan penelitian ini, penulis mengucapkan banyak terimakasih kepada Ketua Asosiasi Ibu Menyusui (AIMI) Sumatra Barat, Ibu Ria Oktorina dan segenap anggota dan pengurus AIMI Padang yang telah banyak membantu hingga terselenggaranya kegiatan penelitian ini. Tidak lupa juga penulis ucapkan banyak terimakasih kepada pimpinan Universitas Tarumanagara, pimpinan Fakultas Ilmu Komunikasi Universitas Tarumanagara dan pimpinan Direktorat Penelitian dan Pengabdian Masyarakat (DPPM) Universitas Tarumanagara, yang telah memberikan kesempatan kepada penulis untuk mewujudkan kegiatan ini.

\section{Daftar Pustaka}

AIMI. (n.d.). Organisasi AIMI. Oktober 18, 2018. https://aimi-asi.org/organisasi. BBC. (2015). Menyusui merupakan sebuah 'perjuangan' bagi perempuan. $\begin{array}{llll}\text { Oktober } & 30, & & \end{array}$ https://www.bbc.com/indonesia/majalah/2015/03/150319_majalah_meny usui

Haroen, D. (2012). Personal Branding: Kunci Kesuksesan Berkiprah di Dunia Politik. Jakarta: Gramedia Pustaka Utama.

Hartoyo, D. S. Nunik Maharani. (2015). Aktivisme Sosial Melalui Penggunaan Media Sosial: Studi Kasus Asosiasi Ibu Menyusui Indonesia (AIMI). Jurnal Kajian Komunikasi, Vol. 3, No. 1, Hal 1-11.

Faizal, AM. (2015). Gambaran Penggunaan Media dan Pendidikan Literasi Media Pada Siswa Sekolah Dasar Di Kota Semarang. Prosiding Seminar Nasional Psikologi dan Media, Unibraw Malang, Semarang.

Kinanti, Syafira Putri., \& Putri, Berlian Primadani Satria. (2017). Pengaruh Media Sosial Instagram @Zapcoid Terhadap Brand Equity Zap Clinic. Jurnal Komunikasi, Vol. 9, No.1, Hal. 53-64. https://journal.untar.ac.id/index.php/komunikasi/article/view/164/643

Kusuma, Hendra. (2018). Pengangguran RI 6,87 Juta Orang, Paling Banyak Lulusan SMK. September 07, 2018. Detik Online. https://finance.detik.com/berita-ekonomi-bisnis/d4009017/pengangguran-ri-687-juta-orang-paling-banyak-lulusan-smk.

Kotler, P. (2013). Marketing Management, 10th ed. New Jersey: Prentice Hall International.

Kriyantono, R. (2007). Teknik Praktis Riset Komunikasi. Jakarta: Kencana Prenada Media Group.

Nasrullah, Rulli (2017). Media Sosial : Perspektif Komunikasi, Budaya, dan Sosioteknologi. Edisi ketiga. Bandung: PT. Remaja Rosdakarya

Windratie, "CNN Indonesia." CNN Indonesia, 29 OKtober 2015. Available: https://www.cnnindonesia.com/gaya-hidup/20151029125442-255-

88143/depresi-pasca-melahirkan-sebabkan-nyeri-menyusui. (Diakses 30 Oktober 2018] 